\title{
The battles in Miami: the fall of the FTAA/ALCA and the promise of transnational movements
}

\author{
Joel Wainwright \\ Department of Geography, Ohio State University, 1036 Derby Hall, 154 North Oval Mall, \\ Columbus, OH 43210-1361, USA; e-mail: wainwright.11@osu.edu
}

\section{Rafael Ortiz}

Department of Geography, University of Minnesota, 414 Social Sciences Building, 267 -19th Avenue South, Minneapolis, MN 55455, USA; e-mail: orti0001@umn.edu Received 4 October 2004; in revised form 14 February 2005

\begin{abstract}
In November 2003 thousands of demonstrators staged protests in the streets of Miami while trade ministers from across the hemisphere met for the Eighth Ministerial of the Free Trade Area of the Americas (FTAA). Accounts of these events tend to rehearse a common narrative about mass urban protests that frame such demonstrations as a conflict between proglobalization governments and antiglobalization activists. This narrative focuses on the physicality of the protests without considering their performative qualities, assumes that state practices and dissent are distinct, mutually exclusive realms of action, and takes 'globalization' to be a scale-fixed process. We call this narrative into question by pursuing two lines of inquiry. First, we analyze the spatial and discursive practices of three different groups of protesters so as to identify crucial affinities and distinctions in their positions and strategies. Second, we challenge the view that capitalist states are simply 'proglobalization' by considering resistance to the US delegation by South American delegations within the FTAA ministerial. From our reading of these events we draw lessons regarding the political and strategic effects of mass urban demonstrations.
\end{abstract}

\section{Introduction}

On 20 November 2003 delegates from all the countries in the Americas, save Cuba, met at the InterContinental Hotel in Miami for the Eighth Ministerial of the Free Trade Area of the Americas (FTAA). ${ }^{(1)}$ The meeting was intended to prepare the negotiations that would bring the FTAA, a multilateral trade liberalization accord patterned after the North American Free Trade Agreement (NAFTA), to completion. The FTAA was to be launched in January 2005, creating the world's largest regional 'free trade' bloc.(2) Like NAFTA the FTAA would reduce certain tariffs between its member states and enact a set of regulations geared to protect foreign investments, but across a trade area spanning nearly the entire Western hemisphere. An impasse between the Brazilian and US delegations, however, pushed the ministers to end the meeting with a less ambitious plan for economic integration. Under the proposed compromise, dubbed, 'FTAA-lite', each state was to comply with a substantially reduced set of obligations, beyond which each state could choose - or not choose - to negotiate additional commitments with any other state or group of states party to the accord. The shift to a nonuniform, two-tier liberalization framework was, despite all assurances offered by the United States Trade Representative (or USTR), a setback for the US trade delegation, which had long pushed for a single, uniform agreement.

As of 1 January 2005, the date of which the thirty-four trade delegations were to reach consensus on the modalities of the final FTAA pact, major areas of disagreement

(1) The FTAA is known as the Área de Libre Comercio de las Américas (ALCA) in Spanish.

(2) We place 'free trade' in scare quotes because the FTAA would sediment certain forms of protection and market regulation. 
remained and negotiations were stalled. The difficulties faced by the USTR make patent that, for the time being, the United States cannot bank on the continued allegiance of certain Latin American states-notably Brazil, Argentina, and Venezuela - to the Washington consensus. The Miami ministerial was, therefore, a watershed moment in hemispheric relations and a challenge to the US neoliberal hegemony. Yet, despite its significance, the summit was scarcely noted by the US media outside Miami (compare Kennis, 2003). And, insofar as the events were covered, stories focused on clashes between police and demonstrators, with little to say about the resulting 'FTAA-lite' in relation to the collapsed World Trade Organization (WTO) ministerial in Cancún, the failure of NAFTA in Mexico, and the shifting political landscape of Latin America.

Such thin analysis of the FTAA meeting was further limited by a common narrative about 'antiglobalization' demonstrations, such as those of Seattle, Quebec, and Genoa. Accounts of these protests tend to frame them as conflicts between proglobalization governments and antiglobalization activists. Yu's synopsis of the FTAA events illustrates this theme:

"While negotiators were busy putting together the trade pact, globaphobes - those who fear or oppose globalization - staged protests outside the conference hotel and in the streets of Miami. Among the protesters were labor unions, environmentalists, anti-poverty groups, and political activists. Although most demonstrations ended peacefully, some protests became violent, and police responded with tear gas, pepper spray, and rubber bullets" (2003).

Here, as in most accounts of the events in Miami, the narrative goes as follows: demonstrators staged protests; some turned violent; the police forcefully dispersed the crowds. There are several problems with this framing of events, besides the psychologism that names the demonstrators. First, it focuses on the physicality of protest without considering the performative aspects of the demonstrations. Accounts may vary as to the appropriateness of the policy response, but attempts to analyze the practices mobilized during the demonstrations are rare. Second, government and dissent are assumed to be distinct, mutually exclusive, opposing realms of activity. By segregating the actors into 'proglobalization' and 'antiglobalization' camps, crucial distinctions and areas of commonality are glossed over. Third, this narrative presumes in advance that globalization is a phenomenon in its own right. Framing these protests as conflicts between 'proglobalization' and 'antiglobalization' camps reiterates the notion that certain social struggles play out exclusively at the global scale. But reifying scales obfuscates the struggles that coalesced in Miami. Presuming that globalization is the terrain of struggle concedes in advance a complex and important question: what is at stake in these conflicts?

This paper is situated at the juncture of two literatures. First, our paper builds on the literature on the FTAA negotiations (Preusse, 2004; Vizentini and Wiesebron, 2004; see also FTAA, 2003). Here our intention is not to offer any novel insights into the likely effects of the FTAA. There is abundant evidence that the FTAA process has been less than transparent (Wiesebron, 2004) and biased towards the USTR negotiating position (Vizentini, 2004). Rather, our intention is to situate the conflicts within the FTAA negotiations alongside the street demonstrations in Miami. Second, and more broadly, our paper speaks to the literature on the dynamics of the 'antiglobalization movement' (see, for instance, Fisher and Ponniah, 2003; Mertes, 2004; Notes from nowhere, 2003; Shepard and Hayduk, 2002). Within this literature, we are particularly interested in complementing those interpretations of urban demonstrations that aim to relate struggles around ostensibly global economic issues with geographical readings of local urban protests. Within this vein are studies of the battles in Seattle (Heyman, 2004; Wainwright et al, 2000), of antidam demonstrations in Bangkok (Glassman, 2002), 
of the protests against the APEC meetings in Vancouver (Pue, 2000) and against the G8 summit in Genoa (Neale, 2002), and of the May Day celebrations in London (Uitermark, 2004). These works show that the micropolitics of protests bear important clues about the broader dynamics of social movements and struggles over urban space (see also Mitchell, 1995; 2003). They also underscore the point that local and global struggles are always coconstituted; as Heyman notes in his reading of Seattle, "the 'global' events in [Seattle's central business district] cannot be severed from the 'local' clashes on Capitol Hill; 'turf' and 'trade' are intertwined (2004, page 54). These studies, moreover, grimly suggest that the conditions of urban protest in the United States and Europe have become increasingly disciplined, if not militarized, since Seattle. ${ }^{(3)}$

Our reading of the events in Miami contributes to these literatures in two broad respects. First, we aim to read the events in a way that calls into question a simplistic 'proglobalization' - 'antiglobalization' bifurcation that pervades the discourse of, around, and apropos mass urban protests. We destabilize the narrative about generic antiglobalization protesters by focusing on the substantive differences in the positions and practices of the heterogeneous multitude. We ask: who came to Miami, and what did they say and do? Where were they active, and how did their politics manifest through sociospatial relations? In answering these questions we concentrate on the sociospatial relations between the diverse groups that opposed the FTAA. We argue that political demonstrations always entail certain material performances of social relations, grievances, and lived practices. Such performances are called 'demonstrations' because they combine bodies, discourses, and spaces in ways that aim precisely to demonstrate what is violent, repressed, or productive within some set of sociospatial relations. In this view, to read a demonstration is to ask what is said, shown, and performed-what spaces are produced, closed off, or opened up - and with what effects. We do not presume, therefore, that the ministerial site was the target of resistance, but rather that multiple demonstrations took place in the streets of Miami-and toward different ends.

Second, we work with the theoretical literature on capitalist states. Following the work of Poulantzas (2001[1978]) and Jessop (1990) we regard the state as a complex ensemble of social relations that is simultaneously: (a) the place-specific outcome, or product, of struggles among different social groups to consolidate competing accumulation projects in order to resolve the contradictions of capitalist development; and (b) the most important arena in which such struggles to make accumulation projects possible take place. In this view it is an error to presume that capitalist states uniformly support neoliberal trade deals, because different states can and do mobilize competing accumulation projects. We find support for this contention in the fact that the failure of the FTAA and the rise of left-leaning, populist states in South America have lent support to projects that rub against the consolidation of a US-led neoliberal hegemony. Alternatives were, therefore, articulated not only outside the ministerial, but inside as well.

\section{In the streets of Miami}

"[T]he protests felt fragmentary ...."

Solnit (2003)

Although the FTAA meetings were barely covered outside south Florida, locally the ministerial and the much-anticipated demonstrations dominated local press coverage. For weeks, the local press echoed statements by meeting organizers and government officials warning Floridians about the thousands of 'anarchists', 'punks', and kindred

(3) Evidence of this trend can be found in a sobering new report by the National Lawyer's Guild (Boghosian, 2004), which catalogs the practices employed by the US government to stifle urban protests. 
'troublemakers' that would descend on downtown Miami to riot and destroy property during the ministerial (compare Delgado, 2003). Miami Police Chief John Timoney characterized demonstrators as "outsiders coming in to vandalize and terrorize our city" (Figueras et al, 2003, page 31A). Reports stressed that the vandals and terrorists would blend in with 'peaceful protesters' to carry out their nefarious plans. By portraying the demonstrations as grounds for mayhem, unlawfulness, and terrorism, government officials stimulated popular anxieties about public security. But this rhetoric-part and parcel of the discourse about mass protests since Seattle, but more so since 9/11 (Lapham, 2004) - not only lent justification to extraordinary police measures. It also framed the discussions about the FTAA meeting. As two commentators observed, the narrative of the 'Miami story' was "aggressively defined from long before the FTAA meeting as protesters versus police" (Hogue and Reinsborough, 2003). Accordingly, the discussions so far have centered on the kinetic physicality of the protests and of the police response, rather than on the political and performative aspects of the demonstrations.

In order to move into a discussion of the performative, we analyze the discursive and spatial practices of three different groups: (1) Root Cause, a coalition of minority and immigrant community-based organizations; (2) the organizations and affinity groups that set out to engage in a 'direct action'; and (3) the United Steel Workers of America (USWA) and the American Federation of Labor and Congress of Industrial Organizations (AFL-CIO) unions more broadly. ${ }^{(4)}$ We emphasize these groups for two reasons: first, they constitute the largest and most visible protest groups in Miami. Second, they reflect distinct political and subject positions. These groupings name different organizational and strategic affinities that were reflected in the practices deployed by each group during the demonstrations. The breadth of tactics deployed by these groups is not the scope of our analysis, however. Of the variegated forms of demonstration that took place in Miami-marches, rallies, educational forums, a street-side tribunal, concerts, civil disobedience, targeted protests against military recruitment centers and retail stores, and more-we focus on the mass public rallies and marches. We do so because of their centrality to each of the group's practices at the demonstrations.

\section{Root Cause}

The first march to take place around the FTAA meeting in Miami was organized by Root Cause, a coalition comprised of three community-based organizations - the Power U Center for Social Change, the Miami Workers Center, and the Coalition of Immokalee Workers - that joined efforts to build a grassroots response to the FTAA ministerial in Miami. ${ }^{(5)}$ For two months before the summit, Root Cause held biweekly community gatherings to analyze the effects of globalization for low-income communities and for communities of color in South Florida. At these meetings participants discussed how pro-market policies have adversely affected their communities by generating unemployment, deepening impoverishment and income inequalities, worsening working and environmental conditions, and encouraging the retrenchment of social services and welfare (Root Cause, 2003). The meetings were also intended to rally support for a 3-day, 34-mile march that set out from Oakland Park, near Fort Lauderdale, and culminated at the perimeter fence surrounding the ministerial site a day before the

(4) For a partial but extensive list of organizations that converged in Miami see http://www.civilsociety.co.il/The\%20Free\%20Trade\%20of\%20the\%20Americas.htm.

(5) The Power U Center for Social Change is a resource center that spearheads grassroots organizing efforts around education and environmental justice issues; the Miami Workers Center is an incubator for community-based organizations around issues affecting low-income communities and low-wage workers; the Coalition of Immokalee Workers is a farmworkers' organization active in the Florida tomato industry. 
delegates were set to convene. Each mile of the route was said to symbolize one country to be subjected to the proposed FTAA.

During the three days of the march, Root Cause activists strolled through residential areas and business districts where low-income communities of African-Americans, Haitians, and Latinos live and work to deliver their 'antiglobalization' message in English, Spanish, and Haitian Creole. With an ever-growing crowd, the activists entered Miami with hundreds of marchers in tow. ${ }^{(6)}$ There, they staged rallies at the Krome Detention Center to protest the confinement of undocumented Haitian immigrants; at a Taco Bell restaurant to booster an ongoing boycott against the fast-food chain for refusing to negotiate better wages with Immokalee tomato pickers; and at the Miami-Dade School Board Building to denounce attempts by the Florida government to further privatize the public education system (Prokosch and LoPresti, 2004). At the end of the march, Root Cause held a rally and concert near the fence despite a large, intimidating police presence (Shaft, 2003).

\section{Direct action groups}

On the day the ministerial opened, two separate rally-and-march events were held in downtown Miami before demonstrators were violently dispersed by police. The first rally-and-march was held in the morning. It was part of a direct action organized by a network of labor, antiwar, animal welfare, anarchist, environmental, and communitybased groups that included, among others, United for Peace and Justice, Global Exchange, the affinity group Carnival Area of the Americas, and the anarchist Black Bloc brigade. According to one sympathetic report, "The intended goal of the [morning] march, agreed upon by representatives of numerous affinity groups, was to take down the fence surrounding the summit in order to disrupt the meeting, or if that was not feasible, to blockade all entrances to the fence in order to prevent delegates from leaving the meeting" (Media Mouse, 2003).

Demonstrators began to gather at the Government Center Park plaza on the intersection of NW 1st Street and 2nd Avenue, two thirds of a mile away from the site of the ministerial (see figure 1, over), at around 7:00 AM. They were flanked by about two hundred heavily armed police officers donning riot gear. As speakers rallied the growing crowd, the police kept watch, duly recording the event with digital video cameras. At about 7:45 AM a crowd of about one thousand demonstrators began marching east on NW 1st Street, then south on NE 2nd Street, and east again on Flagler Street, on its way to the fence on Flagler and Biscayne Boulevard. Police trucks and phalanxes of police in riot gear stood at both sides of each intersection along the route, directing the flow of the march and keeping rogue protesters from abandoning the carnival-like promenade.

At Flagler and 3rd Street the police surrounded the demonstrators and held them in place for close to one hour before they were forcibly pushed onto Biscayne Boulevard and away from the perimeter fence at the intersection of Flagler and Biscayne. Attempts by demonstrators to hold their position near the fence were met with volleys of rubber bullets, contusion grenades, and tear gas. The standoff lasted all morning. Meanwhile, the ministers met undisturbed in a windowless suite, high above the crowd. At about 11:45 AM a line of baton-wielding officers pushed protestors north towards the USWA - AFL-CIO march staging area in front of the Bayfront Amphitheater.

\section{USWA and the AFL-CIO}

The second march held on the day of the ministerial was organized by the AFL-CIO and the USWA with the cooperation of group such as the Alliance for Sustainable Jobs and the Environment, Jobs with Justice, and Citizens Trade Campaign. Hundreds of

(6) Estimates of the numbers of participants range from a few hundred to a thousand. 


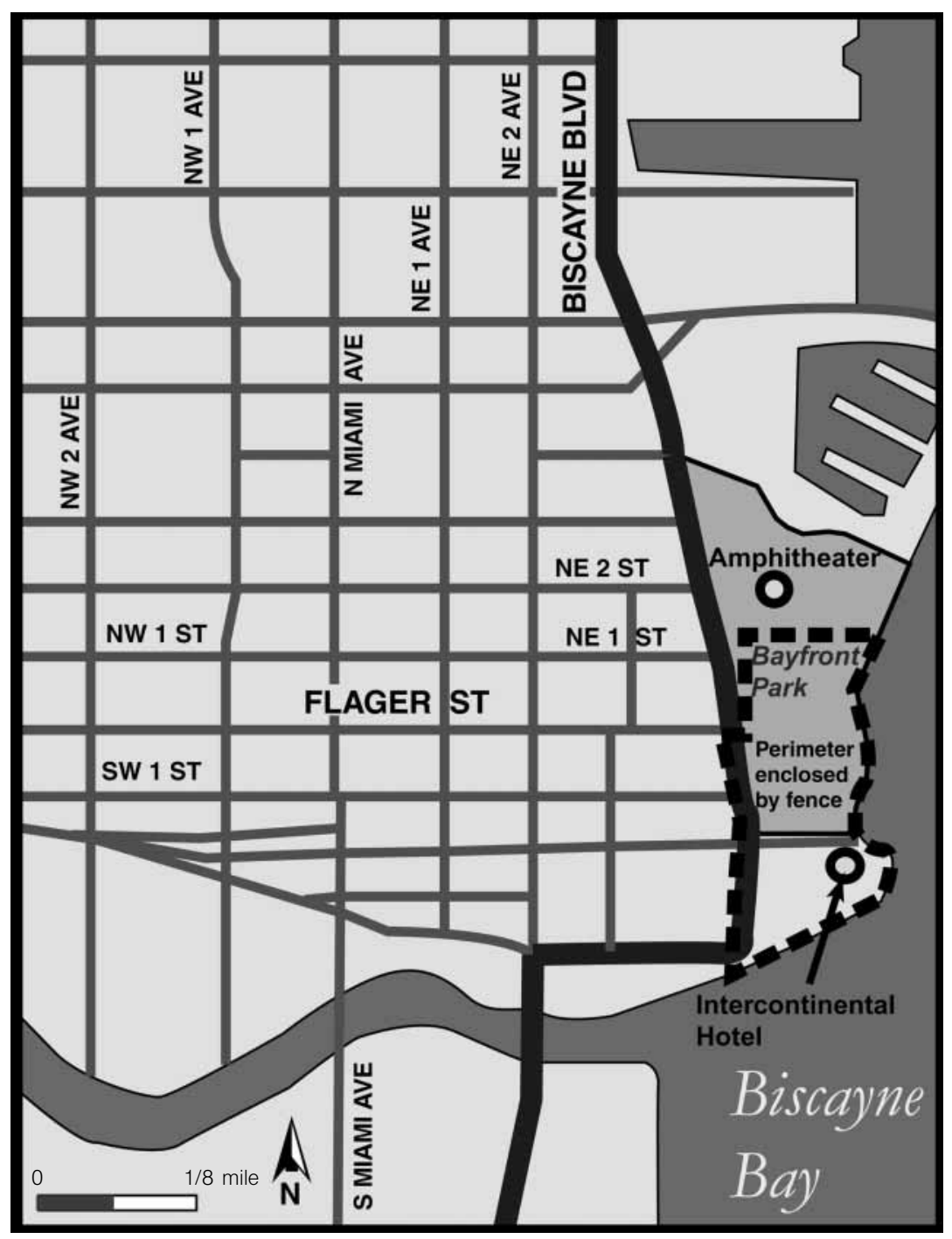

Figure 1. Map of Miami.

steelworkers and other industrial unionists arrived at the staging area, at around noon, in buses that had made their way through the maze of checkpoints and closed streets in the downtown area. The awaiting AFL-CIO ushers vigorously encouraged the unionistsreadily identifiable by their union T-shirts - to enter the amphitheater and listen to speakers and musical acts while waiting for the march to start. Those without a union T-shirt were patted, and their bags thoroughly searched, on their way into the amphitheater. Inside the venue several speakers called for international solidarity against the calamities of free trade. Mexican and Brazilian labor activists made impassioned speeches about the effects of NAFTA and of corporate globalization. Haitian and Latino members of UNITE gave testimony of their plight for better salaries and working conditions in the United States. The crowd, however, comprised mainly white steelworkers from the rust belt, who criticized the FTAA for taking jobs away from the United States.

After the rally inside the amphitheater, AFL-CIO ushers lined up the different groups that were to participate in the march on Biscayne Boulevard. At the head of 
the march were the AFL-CIO unions with the USWA prominently in front. Behind them were the 'civil society' groups that had officially joined the labor march. The direct action folk stood at the end. A clear spatial separation divided the direct action folk from the labor and civil society contingents. A human cordon of AFL-CIO ushers not only created a buffer between unionists and police, but also attempted to keep potential troublemakers in the direct action crowd out. ${ }^{(7)}$ Shorter than planned, the march set out from the staging area in front of the Bayfront Amphitheater, moved west onto NE 3rd Street then north on 1st Avenue, looping around downtown, and returning to Biscayne on NE 2nd Street. Though the march was not allowed to proceed south on Biscayne toward the fence as originally stipulated in a permit obtained by organizers, it proceeded without incident.

Once the march returned to the staging area, most unionists quickly retreated to the amphitheater to wait for their buses. Just as in Seattle, most industrial unionists left downtown Miami within an hour. The direct action people and a few unionists stayed behind on Biscayne Boulevard. At around 5:30 PM, some of the most intrepid elements of the direct action crowd rushed the police line that separated them from the fence on Biscayne. The police responded violently as they moved in to disperse the crowds with batons, tear gas, tazers, and pellet guns.

\section{Discerning political spaces}

Most narratives of Miami treat the demonstrations as if they all took place simultaneously, in the same space, towards a common 'antiglobal' end. Our account challenges this narrative in two key respects. First, the three demonstrations occupied quite different spatial and temporal positions during the FTAA events. Root Cause activists took to the streets a few days before the ministerial and demonstrated both inside and outside the city center. Although the USWA and direct action demonstrations took place in the city center on the same day, they were clearly separated in time and space. Direct actions occurred before and after the labor march. Moreover, during the labor march, the spatial organization of the group segregated the mass into two distinct groups: unions and their official allies in the front; direct action groups in the back, submitted to union discipline.

Second, the three groups deployed different discursive and spatial tactics during the demonstrations. The USWA and other AFL-CIO industrial unions went to Miami to deliver a message against 'free trade' and 'globalization', in general, and against the elimination of US tariffs on steel, specifically. The latter motivation not only made the USWA and the steel industry odd bedfellows - the US steel industry endorsed and partly subsidized the union activists during the FTAA meeting ${ }^{(8)}$ - but it also translated into an unwillingness by the USWA to engage in anything else but the mass mobilization of bodies to downtown Miami to show support for its cause. In contrast, the earlier march organized by the direct action groups also tried to deliver a message, by attempting to disrupt and, if possible, derail the FTAA meeting. According to one prominent direct action organizer:

"The direct action strategy in contesting the summits is not really about physically disrupting them. It's about undermining their legitimacy, unmasking them, making visible their inherent violence and the repression necessary to support them and undercutting public belief in their beneficence or right to exist" (Starhawk, 2003).

(7) This policing of the amphitheater and march revealed deep differences in sociospatial tactics employed by the USWA and the direct action groups. Such strict disciplining of union involvement in the protests was also decisive to the battles in Seattle (compare Wainwright et al, 2000).

(8) Rafael Ortiz was invited by United Students Against Sweatshops to join the USWA demonstrations against the FTAA. The USWA covered the costs of his transportation and lodging for the trip with funds provided partly by the US steel industry. Our paper, therefore, benefited from this assistance. 
In this view, the direct action strategy is radically different from that of the USWA. The logic is not to mobilize bodies as quantitative support for a message, but to make the violence of the state against the bodies-in-protest the message itself. Hence it is both more symbolic and more 'direct'. A third set of tactics was used by Root Cause. The latter also set out to deliver a message, but decided to do so not in the desolated streets of downtown Miami but by interacting with the very communities that stand to be most affected by the implementation of the FTAA. ${ }^{(9)}$

In sum, the protests felt fragmentary to many activists because the three largest contingents - the unions, the direct action groups, and Root Cause-were separated in time and space, and used different tactics to deliver their message of disaffection. Yet the FTAA ministerial was a failure, despite the absence of a coherent anti-FTAA movement outside the conference center. The fall of the FTAA ministerial came about as a result of a rather different set of dynamics.

\section{Inside the conference center}

"[T]he dream of a hemisphere united into a single free-market economy died last week. It was killed not by demonstrators in Miami, but by the populations of Brazil, Argentina, and Bolivia, which have let their politicians know that if they sign away any more power to foreign multinationals, they may as well not come home."

Klein (2003)

Notwithstanding the media's emphasis on police-protestor clashes, in a strong sense the FTAA negotiations were over before the battle erupted on Biscayne Boulevard. Indeed, the substantive negotiations concluded even before the start of the ministerial. So opposed were the two major positions that no meaningful negotiations could take place in the Miami conference; there was only enough space for the delegates to agree formally to disagree. This raises several questions: what led to this (dis)agreement, and what are its effects? And where do these 'internal' events stand in relation to the clashes on the streets outside?

When delegates came to Miami in November 2003 they faced the deepest impasse over negotiations since the process to create the FTAA was initiated at the Summit of the Americas in 1994. Several factors contributed to make Miami a decisive point in negotiations. By 2003 the somber results of NAFTA for Mexico were widely recognized. Notwithstanding the increase in most exports from Mexico to the United States, since the inception of NAFTA in 1994, Mexico's economic growth has slowed (Weisbrot et al, 2004). ${ }^{(10)}$ Conditions for the middle classes, working classes, and peasantry have deteriorated: Mexican workers' wage rates have fallen in real terms (Diebel, 2001; Public Citizen, 2003). Maize prices received by Mexican farmers have fallen by $70 \%$, even as food prices in urban areas increased (Public Citizen, 2003, pages 1-2). Such results, coupled with a broader wave of resistance to liberalization and structural adjustment throughout South America, have generated widespread skepticism - even among Latin American elites - that a US-led neoliberal agenda is unlikely to create the conditions for sustained economic growth.

Moreover, the recent sweep of electoral victories for left-leaning candidates in South America has shifted the discourse around trade and development policies for

(9) It is important to note that the USWA held a number of educational workshops, press briefings, and protest rallies across the United States in anticipation to the FTAA ministerial.

(10) Weisbrot et al show that a widely cited World Bank study suggesting that the Mexican economy grew at a faster rate than expected because of NAFTA was based on flawed data. Faux (2003) summarizes the effects of NAFTA as follows: "the Mexican middle class has shrunk and the number of poor has expanded. Economic growth has been below the old corporatist economy's performance." 
the hemisphere. Campaigns critical of neoliberal policies ushered Hugo Chavez (1998), Luiz Inacio Lula da Silva (2002), and Nestor Kirschner (2003) to power in the three largest South American economies. Although it is too soon to know how effectively these states will be able to reorient their economies, they have already opened spaces for challenging the Washington consensus. In September 2003, two months before the Miami FTAA meetings, Brazil played a key role in the collapse of the Fifth Ministerial of the WTO in Cancún. At Cancún the United States and Europe proposed to bring four new suites of policies - the so-called 'Singapore issues' - under the purview of the WTO. The ministerial ended with no new agreements after a new coalition of developing economies successfully resisted pressures from the United States and European Community (EC) to bring new, contentious issues into the WTO. Antagonized by the refusal of the United States and Europe to reduce their export subsidies for agriculture, coupled with the US-EC insistence that developing countries accept the Singapore issues, the G20+ was emboldened to unite and reject the draft ministerial text. ${ }^{(11)}$ Brazil led the G20+ with China and India.

At the conclusion of the Cancún ministerial the USTR argued that, because of the failure of the Doha round, the United States would pursue regional and bilateral trade agreements. But the FTAA - precisely the sort of US-dominated regional agreement that was touted as a 'freer' alternative to the $\mathrm{WTO}^{(12)}$ - appeared to be in distress in the weeks leading up to the Miami ministerial. Miami was in some sense Cancún redux, with two fundamentally opposed demands dividing the Brazilian and US delegations: on one hand, the refusal of the United States to reduce its agricultural export subsidies, and, on the other, the refusal of Brazil to commit to across-the-board liberalization of finances and trade in services. Both states worked to line up allies behind their positions in the months between the two events. ${ }^{(13)}$ And, although the USTR was able to convince certain states to leave the G20+ (such as Colombia and Costa Rica), Brazil, Venezuela, and Argentina remained in the group. Without these economies, US elites had little to gain from the FTAA. ${ }^{(14)}$ The USTR was in a bind: unable to win over Brazil and Argentina, the FTAA could not move forward on the United States' terms; but the USTR wanted to avoid a second major defeat in three months. Thus the USTR

(11) This group comprised a union of the G20+ with the African Group, the African, Caribbean, and Pacific group, and the Least Developing Countries. At Doha developing countries insisted on language that said the new issues would not be taken up in Cancún without an 'explicit consensus' by WTO members. The debate in Cancún was framed by the Draft Cancún Ministerial Text, released by the WTO only weeks before the ministerial (the draft text was not released through the usual process whereby the WTO secretariat hammers out a draft text after meetings with member states, but was prepared by the chairman of the General Council 'on his own responsibility' (see WTO, 2003). The text made no guarantees of reductions of farm subsidies and yet demanded that developing countries accept two of the new issues. The final collapse occurred when EC Trade Commissioner Pascal Lamy insisted that the new 'Singapore' issues by discussed first in the final negotiations. Nine months after Cancún, Brazil and India capitulated to the United States and EC, which led to the signing of a new round of WTO negotiations (WTO, 2004a; 2004b). The agreement, signed on 31 July 2004 in Geneva, guarantees no reduction in developed-country farm subsidies or expanded market access for developing countries, but introduces one of the new issues, trade facilitation, into the WTO purview (Bello and Kwa, 2004).

(12) The FTAA is 'WTO plus', meaning that its provisions go above and beyond those of the WTO.

(13) For a useful analysis of the Brazilian state's approach to the FTAA see van Rompay (2004).

(14) In the run up to the Miami ministerial, the United States focused its lobbying on Argentina, which sided decisively with Brazil in the run up to the Miami meeting. Talks between Brazil and other Central and South American leaders accelerated after Cancún and Miami. On 16 March 2004, Lula and Kirschner released The Declaration of Cooperation for Economic Growth with Equality, a manifesto for development and collaboration between South American states (Kirchner and Lula da Silva, 2004). 
conceded the most important point in the FTAA negotiations to the Braziliansflexibility in commitment. The language of the Miami ministerial declaration states:

"Ministers recognize that countries may assume different levels of commitments. We will seek to develop a common and balanced set of rights and obligations applicable to all countries. In addition, negotiations should allow for countries that so choose ... to agree to additional obligations and benefits" (FTAA, 2003, point 7 , our emphasis).

This language, which owes much to the Brazilian drafts written months before the clashes on Biscayne Boulevard, gives enormous room for states to maneuver. The United States was therefore forced to concede to Brazil the central element of the negotiations over the FTAA: whether the agreement would compel each member state to adopt all provisions or whether states could opt out of sections of the FTAA agreement. As a consequence of Brazil's victory, member states could participate in the FTAA without conceding to the ministerial's rule on contentious issues, such as agriculture, intellectual property, and investment policy. ${ }^{(15)}$ In the words of Wallach (2003), the US capitulated "from its 'single undertaking' vision of the FTAA to an à la carte approach to ensure that the FTAA lives to stagger on another day" (page 1).

Interpretations of the outcome in the US press were generally brief and misleading. The Associated Press report on the ministerial outcome comprised two sentences, both factually incorrect:

"Trade ministers from across the Americas, initially swamped by disagreement, gave final approval Thursday to a buffet-style framework for the world's largest free trade bloc. Although the meeting was scheduled to end Friday, ministers sped up negotiations and reached agreement on an outline for the proposed [FTAA], according to a spokesmen for the US and Caribbean delegations" (Associated Press, 2003).

In this narrative, which reflects the US delegation's 'spin', the various ministers overcame their initial disagreements to give approval for a framework that allows the FTAA to move forward. But negotiations were not 'sped up'; they ended early, and not in agreement but in deep disagreement. The proliberalization magazine The Economist (2003) portrayed the events more accurately, noting that the agreement did not constitute "the ambitious, comprehensive approach that Mr Bush once wanted".

All signs suggest that the FTAA is barely staggering on. Talks resumed at the 'Special Summit of the Americas' on 13 January 2004. The only mention of the trade agreement in the summit's official statement, the "Declaration of Nuevo León", frames the FTAA as a process of improving agricultural market access for developing economies:

"We recognize that liberalization of trade of agricultural products constitutes, inter alia, an essential element for the development of agriculture in the countries of the Hemisphere. We therefore reaffirm our commitment to trade negotiations to promote effective access to markets" (FTAA, 2004). ${ }^{(16)}$

Formally, the FTAA Trade Negotiations Committee (TNC), cochaired by Brazil and the United States, continued to meet through the first half of 2004. But at the end of four post-Miami meetings the only statement from the committee was that

(15) Additional factors surrounding the USTR's concession include the upcoming US presidential election and the campaign by the city of Miami to become the permanent host of the FTAA ministerial.

(16) Venezuela added a note to the text at this point: "Venezuela enters a reservation with respect to the paragraph on the Free Trade Area of the Americas (FTAA) because of questions of principle and profound differences regarding the concept and philosophy of the proposed model and because of the manner in which specific aspects and established timeframes are addressed." 
"the delegations need more time". (17) The committee was unable to move beyond the stage of holding informal consultations, and no firm deadlines for broader FTAA negotiators had been set. Venezuelan President Chavez's reading of this failure was that the FTAA was 'dead'. (18) Chavez's view is consistent with those voices on the left that detected a significant turn when no concrete deadlines were set in Miami. In the face of polarized negotiating positions without a clear agenda, a series of meetings after the Miami ministerial brought no forward movement along the US-oriented path. As Wallach reports:

"Trade negotiators from nine countries of the proposed 34-nation FTAA met in Buenos Aires on March 31 and April 1 [2004] ... to resolve several key deadlocks and build consensus about a common set of FTAA obligations that countries could approve at a planned April Vice Ministerial Trade Negotiating Committee (TNC) scheduled for Puebla, Mexico. They did not succeed. This meeting's implosion follows the collapse of an early February 2004 TNC meeting in Puebla and an early March meeting in Buenos Aires .... Both meetings ended with acrimony and without agreement. Now, for the third time in a row, this week's 'save-the-FTAA summit' has collapsed" (2004, page 1).

With the benefit of hindsight we conclude that the USTR's goal of leading Brazil and the rest of Latin American towards the January 2005 deadline to begin the FTAA was defeated by May 2004. ${ }^{(19)}$ From the anti-neoliberal perspective, this appears to be a great victory. It is in this spirit that Bello declared Miami a 'victory' for 'the anti-FTAA side'. He cities the anonymous report of a delegate to the ministerial:

"As the Latin American negotiator put it, 'Brazil was saying, look, 2003 is different from 1994, when Clinton launched the FTAA negotiations. Free trade policies have brought about bad results throughout Latin America. People have ousted neoliberal governments. There was no way the US was going to get the comprehensive free trade agreement it wanted today' To the surprise of many, the US agreed to the Brazilian compromise a few weeks before Miami" (Bello, 2003).

Assuming the accounts by Wallach and Bello are correct, we are left to ask: why was Miami not widely celebrated as a victory among the US left? In contrast with Seattle, practically no celebratory pulse moved through activist circles - no surge of excitement about 'the battle of Miami'.

We can extend several responses by reconsidering the different geographies of resistance in Miami. From the perspective of the direct action groups, Miami was a failure because the conference center remained open and the demonstrations were thwarted by the police. From the perspective of the USWA (the largest group among the nongovernmental organizations and unions) the loss of the steel-import tariffs which was determined to be an illegal subsidy to the steel industry by the WTO — cast a

(17) The meetings were on 6 February, 10 March, 1 April, and 3 May 2004. See FTAA.TNC/com/ 01, FTAA.TNC/com/02, FTAA.TNC/com/03, and FTAA.TNC/com/04 (http://www.ftaa-alca.org/ alca.org_e.asp). After the April meetings the cochairs of the TNC agreed that "further progress is necessary before resuming the seventeenth meeting of the TNC" (FTAA.TNC/com/03). After the May meetings the cochairs of the TNC stated "that there is a need to continue informal consultations and [the TNC] will meet again later in May in order to make further progress in the FTAA negotiations" (FTAA.TNC/com/04).

(18) "Hugo Chavez said ... [the] US plan to create [the FTAA] was 'dead' after the suspension of scheduled talks on the project he fiercely opposes. The next formal trade negotiations between the 34 Western Hemisphere nations were to have been held in late April but officials said Thursday they were being suspended .... No new date was set. 'It's a fact, the FTAA is dead'" (Reuters, 2004).

(19) At the time of writing (February 2005) we find no signs that the FTAA may be revived. This could change, of course, if the political direction of Latin America shifts. 
large cloud over its effort in Miami. These two points show one of the limits of such 'antiglobalization' activism: its relatively weak transnational alliances. ${ }^{(20)}$ Above all, Brazil's 'victory' in Miami was not celebrated in the United States because it was not recognized as a victory. ${ }^{(21)}$ This raises the question of how political goals come to be recognized as such within heterogeneous social groups such as those that oppose the FTAA.

\section{Discussion: the polis and bios}

"This is modern democracy's strength and, at the same time, its inner contradiction: modern democracy does not abolish sacred life but rather shatters it and disseminates it into every individual body, making it into what is at stake in political conflict."

Agamben (1998, page 124)

In this section we want to draw out two sets of arguments from our reading of the events in Miami. Our first set of arguments concerns the spaces and effects of urban demonstrations. After the demonstrations in Miami there was considerable discussion about the relative 'success' or 'failure' of the protests; most US-based activists who went to Miami were disappointed with the results of their protests. In a typical internal critique, one activist wrote that "police repression, poor planning and undue emphasis on mass mobilization [made the] much-hyped day of action November 20 a bust" (Anzaldo, 2004). In this view the restriction of movement was so extreme that the demonstrations had no hope of having an immediate effect. One writer concluded: "if anything was achieved, it was the extension of police state adventurism, and the slow commonplacement of the hypothesis that political dissent ought not to be distinguished from terrorism" (Clover, 2003, page 43). Clearly, state practices since Seattle have intensified and police tactics curtail dissent. According to the National Lawyers Guild report:

"Policing tactics during demonstrations include establishing screening checkpoints; creating so-called free-speech zones; conducting mass false arrests and detentions; employing pop-up lines; using dangerous rush tactics with police on motorcycle, bicycle, and horseback; and using deadly 'less lethal' weapons. Other tactics include closing streets and public sidewalks to people who are not carrying event-approved identification, and stationing police with video cameras on rooftops and deploying officers to photograph and film people in the area, including people who are not attempting to enter restricted zones" (Boghosian, 2004, page 43).

(20) We distinguish transnational from international to refer to the quality of connection between social groups from different states and territories, which may complicate or call into question the national identities of those within the given state territories. In this view, international movements connect distinct national groups; transnational social movements transcend boundaries and, in so doing, seek to undermine narrow forms of nationalism. We draw this distinction to clarify the degree to which national essentialisms form the basis of particular international alliances. This distinction can be derived from Marx and Engels's analysis of nationality in the Communist Manifesto (1848), viz: "The Communists are further reproached with desiring to abolish countries and nationality. The working men have no country. We cannot take from them what they have not got. Since the proletariat must first of all acquire political supremacy, must rise to be the leading class of the nation, must constitute itself the nation, it is so far, itself national, though not in the bourgeois sense of the word."

(21) We are not suggesting here that the state of Brazil, or any Latin American state, transparently represents the aspirations of those it governs. We take the state to be a complex ensemble of social relations that is the product of negotiations, settlements, and struggles among different social groups. There is, however, a conjunctural affinity between the 'antineoliberal' stands of the populist governments of Brazil, Venezuela, Argentina, and Bolivia, and the US 'antiglobalization' movement. 
Miami was no exception. Even prior to the arrival of the protestors the Miami police closed off most of downtown Miami. Businesses were secured or closed; fences erected; residents were encouraged to leave town. Weeks before the ministerial, the Miami City Council passed a constitutionally suspect ordinance requiring a permit for any 30 -minute-long gathering of seven or more people, and prohibiting certain protest props, such as puppets and picket signs, in the city. The police carried out 'preemptive arrests' of 'suspected anarchists' and harassed activists preparing for the demonstrations. Downtown public transportation was curtailed and businesses were advised to remain closed during the summit. As demonstrators converged in downtown Miami they found a perimeter fence surrounding the ministerial site, state-of-the-art surveillance helicopters hovering above the city, armored vehicles in the streets, and thousands of riot-gearclad police officers armed with an assortment of 'less-than-lethal' weapons, including batons, contusion grenades, tazers, pepper spray, tear gas, and rubber-bullet guns. The containment of protests within 'free-speech' zones, the use of ostensibly 'surgical' police interventions (to remove potentially violent individuals), the framing of urban demonstrations as 'threats to public security', and the conflation of 'protest' with 'conflict' all serve to inoculate attempts to argue that police practices are illegitimate. Collectively these practices empty the polis in its dual sense-as urban center and gathering space of political life.

The US state has become adept at disciplining dissent through the regulation of urban space. As a result of such practices one effect of the march-its effect as a direct and material demonstration of the popularity and importance of criticisms of the FTAA - was practical nil. A crowd of thousands marched, chanting, through an empty city, their voices echoing off empty towers. The only audience for the performance consisted of the police and corporate media.

This panorama forces us to raise some difficult points. Large political demonstrations in the United States today take a predictable form: people gather, listen to a few speeches, and march through the center of a city. But as most urban cores have been largely depopulated, left 'full' of empty glass towers - and because civil rights are effectively suspended by intensified police practices that take exception to civil rights - these marches pass through cities without bringing about face-to-face interactions between protesters and other citizens. (To march by the houses of the rich would require tracing a winding path through the suburbs; to march by the poor would lead the marches through the ghettos: these options are rarely pursued.) Without direct engagements between citizens as political actors, the messages of political protests are left to propagate through representations of the event in the news media. Ordinarily this implies a few images from the march, coupled with one statement (from an interview or speech of a 'protest leader') as to the 'point' of the demonstration. Moreover, the possibility that a demonstration would disrupt 'business as usual' (through the very act of knotting up urban spaces) is often formally abandoned by protest organizers in advance as a condition of securing a legal permit to gather or march. Under these circumstances activists must place great emphasis on articulating one clear sound bite and a strong image of the protest - by summoning large numbers of people to a well-disciplined march. In sum, what large marches today demonstrate, fundamentally, is the quantitative support for a sound bite.

This reduction of the demonstrative, performative quality of political protest, coupled with the disciplinization of urban space, has important effects for the very constitution of political subjectivity. One indication of these effects is that would-be demonstrators must carefully weigh whether to carry personal identification (which could be used against them if they are swept up in group arrests) and whether to wear a mask. A second clue is that the accountability of demonstration size has assumed great importance. It is common practice today for both the police and the protest organizers 
to count the turnout. ${ }^{(22)}$ A third effect is the intensification of internal political battles over representation; that is, over who gets to head up the march or speak to the television cameras.

These effects suggest a broader, more profound implication. The loci of protest have shifted, not in terms of the purpose or object of protest but at the level of subjectivity. To borrow terms of analysis from Agamben's reading of the figure of Homo sacer (1998), we suggest that the demonstrating subject is today rarely possible as bios - as speaking subject - without zo $\bar{e}$ - the biological body, the body in the street. ${ }^{(23)}$ How are citizens expected to demonstrate today? By a willingness to place their bodies in a crowd, in an empty city, before the police. Perhaps this explains a desire, often strong among young privileged activists, for a direct confrontation with the police. If the essential character of a political act is reduced to the demonstration that one has a body and that one is willing to place it in front of the police, in the street, then how could this not solicit such a desire (as evidence of the capacities of bios politikos, as a demonstration of a way of living proper to a thinking, democratic being)? ${ }^{(24)}$

Given the circumstances in which their actions took place, the USWA and the direct action groups could hope to achieve only limited success. There was no interaction with the body politic other than through the mediation of the corporate media. The role of spokesperson for the protests was effectively captured by the USWAwhich used this role to demonstrate that US steelworkers oppose the FTAA and stand up for US jobs. The direct action groups' attempt to deliver a message by taking urban space could be more effective, if not for the nature of the disciplinary tactics and technologies deployed against them. In such an environment the challenge is for protesters to devise creative practices that circumvent the state's monopoly over spaces of dissent-while simultaneously searching for opportunities to create new alliances. We would argue that the Root Cause march constituted one such creative instance. Instead of staging protests in proximity to the ministerial site in the hope of obtaining a sound bite and an image, Root Cause emphasized transnationalism, movement, and alliance-building among the working class.

And yet we stress that South American states, and not Root Cause, brought about the fall of the FTAA. This brings us to our second set of arguments, which concerns scale. At the Miami protest, as in Seattle, the conference center itself was taken as the object of the protest. In spite of their spatial and tactical differences, the main aim of the different protest groups was to get as close to the InterContinental Hotel as possible and occupy urban space. The USWA and its allies staged a rally in the Bayfront Amphitheater before promenading through the city center; the direct action groups,

(22) A genealogy of this practice would be useful. Our first memory of such a disciplined counting program was in 1993, at the gay, lesbian, and bisexual rights march in Washington, DC. Everyone was asked to sign a petition indicating that they had come to the demonstration. The National Park Service used aerial photographs to produce another, lower estimate of turnout.

(23) In Homo Sacer, Agamben notes that the Greeks had two distinct terms to speak of life: $z o \bar{e}$ and bios. Bios referred to a way of being particular to a kind of life; zoe referred to life itself, stripped away of its qualities. Thus, one would speak of 'political life' as bios politikos; but "to speak of a $z o \bar{e}$ politike of the citizens of Athens would have made no sense" (Agamben, 1998, page 1). Agamben argues that "the entry of $z o \bar{e}$ into the sphere of the polis - the politicization of bare life as such-constitutes the decisive event of modernity (page 4).

(24) We contend that the clearing and securing of Miami's urban space during the protests characterize what Agamben has called the 'sovereign exception' in sociospatial form (1998, section 1, passim). Apropos this condition, Agamben writes: "Everything happens as if, along with the disciplinary process by which State power makes man as a living being into its own specific object, another process is set in motion that in large measure corresponds to the birth of modern democracy, in which man as a living being presents himself no longer as an object but as the subject of political power" (1998, page 9). 
unable to tear down the perimeter fence, settled for occupying Biscayne Boulevard and forcing a confrontation with the police; even Root Cause's 34-mile march a few days earlier culminated at the fence. All took the ministerial site as the main target of their actions. This suggests that there is an underlying link between the antiglobalization discourses of the different protest groups and a kind of localism that finds proximate, 'direct' action at the sites of ostensibly 'global power', such as the InterContinental Hotel, as the most genuine, authentic, immediate, or effective form of resistance.

We hypothesize that there is a link between such identification of the conference center as the object of the demonstration and the broader view that the purpose of the protest is to stop globalization. The link is forged through a two-part translation. First, the political problem is defined in terms of 'globalization' (understood as a kind of extralocal, totalizing process). Accordingly, the solution is defined as the confronting of global power wherever it touches down, as with the FTAA meeting. This way of fixing the scale of the protest has notable effects on strategy. First, in heavily policed urban spaces, a movement that defines its goals in terms of closing buildings is practically doomed to fail. The 'arms race' of protest (as well as the US state's response to 9/11) has facilitated investments in police technologies, and the US state today enjoys a profound capacity for controlling urban space. Opportunities to recreate the conditions that led to the closure of the Seattle Conference Center in 1999 seem remote. It is no surprise, then, that the protestors in Miami were unable to reach the conference center, let alone close it down. What is surprising is that this tactical limit came to define the broader demonstration as a failure-notwithstanding the fact that the basic aim of the protests, to forestall the start of the FTAA, was accomplished.(25) Second, by focusing too concretely on the sites where 'proglobalization' meetings are held, we stand to ignore key differences and struggles within them. Just as it would be wrong to assume that everyone outside the InterContinental Hotel shared a common purpose, it is meaningless to conflate all states and their representatives - and then equate them with some abstract force ('globalization'). Underlying these two points is a general problem with this way of interpreting the scale of political struggle: a narrative that defines the problem as 'globalization' threatens to obscure two key points. First, the practices that constitute 'globalization' as such are manifest everywhere, albeit unevenly; and, second, struggles for justice are not necessary tied to one particular scale.

\section{Conclusion}

Relative to the attention that was given to the battles in Seattle, those in Miami were poorly covered in the US media and declared a failure by many US activists. Whereas the events in Seattle became the theme of a whole raft of books and research, the scholarly response to those in Miami has been modest. Yet, ironically, for the livelihoods of peasant and working-class people across the hemisphere, the result of the 'battles in Miami' may prove to be more significant than the events in Seattle.

There were two major differences between these events. First, in Miami the relation between the recognized civil society organizations was at the front of the protest, rather

(25) The tension between the 'defeat' of the street protests and the collapse of the FTAA is born out in a documentary firm, The Miami Model (FTAA Miami Video Working Group, 2004), produced shortly after the Miami protests by a filmmaking collective. The film documents the dynamism of the activist groups and the intensity of the police attacks on protesters. However, there is a striking gap in the film between the density of images of the protest and the coverage, or analysis, of the conflicts between the different nation-states. The absence of analysis of the divisions between states creates some confusion in the final seconds of the film, where the viewer is told that "The FTAA stalled in Miami". This true, but unexplained, comment suggests that the protests somehow stalled the FTAA. 
than on the other side of the city (although only up until the moment before the police assault on the protest was initiated). For Klein the most striking aspect of the Miami protests was "how divorced the security response was from anything resembling an actual threat. From an activist perspective, the protests were disappointingly small and almost embarrassingly obedient" as a consequence of "weeks of police intimidation" (2003, page 1). Relative to the demonstrations in Seattle in 1999 and in Washington, DC, in 2000, the numbers of protesters in Miami were indeed modest, largely because two key coalitions from Seattle skipped Miami: the so-called 'Teamsters and turtles'. With the exception of the USWA, none of the large AFL-CIO unions encouraged workers to protest in Miami; environmental groups played a modest role. Another difference concerns the level of coordination among leaders of developing states. Relative to the resistance to the US-EU positions seen in Seattle, leaders of South American states held a stronger, more focused position before the Miami meetings. In each case, the anti-US coalition succeeded in preventing further erosion of its position, but the results were more clear in Miami: the FTAA as we knew it met its demise.

Perhaps the most important commonality between the battles in Seattle and those in Miami was the failure to recognize and build upon transnational alliances. The linkage between globalization rhetoric and activist practices (and the undue emphasis on the physical sites of these meetings) underscores the need for such alliances. The general argument here is that building transnational networks - which always involves the difficult work of translation, negotiation, and alliance building - is necessary to change the terrain on which struggles over trade and economic policies, such as the FTAA, unfold. This argument relates to three specific points. The first is that 'antiglobalization' discourses often obscure the fact that alliances between different subaltern social groups, however geographically dispersed, have more room to maneuver when the groups stand in solidarity with one another. Few things are as 'global' as the so-called 'antiglobalization' movement, and its complex geographies constitute one of its great strengths. Second, these transnational alliances must take advantage of the fact that many developing states oppose broad aspects of US and European Union economic and foreign policy. As different states mobilize competing accumulation projects (themselves the outcome of struggles between different social groups and capital), subaltern groups can strategically ally with fractions of certain states. And, third, for transnational alliances to extend through the territory of the US state, they must produce less-regulated spaces for dissent. As Mitchell (2003) notes, the political rights to move and protest must be continually reproduced: "the right of groups and individuals to make their desires and needs known ... such a right cannot be guaranteed ('accepted') in the abstract-rather, it is something always to struggle toward. In this struggle ... a place in which groups and individuals can make themselves visible is crucial" (page 33). As these struggles always transcend the boundaries of nation and territory then effective movements to reproduce rights must do so as well.

Acknowledgements. We would like to thank Jim Glassman, Rich Heyman, Gerry Pratt, and two anonymous reviewers for criticisms of earlier drafts of this paper, and Jason Jindrich for the map. Rafael Ortiz would also like to thank the United Steelworkers of America (USWA) and United Students Against Sweatshops (USAS) for sponsoring his research in Miami. Joel Wainwright conducted some of the research for this paper with support from an Izaak Walton Killam Fellowship at the University of British Columbia. We are solely responsible for errors.

\section{References}

Agamben G, 1998 Homo Sacer: Sovereign Power and Bare Life (Stanford University Press, Stanford, CA)

Anon, 2003 Bras, bolts and Brazil" The Economist 22 November, page 32 
Anzaldo L, 2004, 'Miami's mixed bag: solidarity and misdirection”, http://ftaaimc.org/or/2004/01/ 3503.stml

Associated Press, 2003, "Conference ends early as ministers agree to buffet-style outline for FTAA", Miami, FL, 20 November

Bello W, 2003, "Original FTAA vision scrapped as people pour into Miami for anti-free trade protest", International Forum on Globalization website, http://www.ifg.org/news/ftaa/ ftaascrap.htm

Bello W, Kwa A, 2004, "G 20 leaders succumb to divide-and-rule tactics: the story behind Washington's triumph in Geneva", 10 August, http://www.focusweb.org/trade/html/ modules. php?op $=$ modload \& name $=$ News \&file $=$ article $\&$ sid $=249$

Boghosian H, 2004, "The assault on free speech, public assembly, and dissent: a National Lawyers Guild report on government violations of First Amendment Rights in the United States", http://www.nlg.org/resources/DissentBookWeb.pdf

Clover J, 2003, "Storm clouds: FTAA — big capital brings its dark circus to Miami" Village Voice 26 November, page 43

Delgado C, 2003, "Whole world watching as Miami prepares to host the hemisphere's trade ministers, free-trade protesters get ready for action" Miami New Times 17 July, http://www.lexis-nexis.com

Diebel L, 2001, "NAFTA largely a failure for workers: notes job loss, lower wages and labour standards in three nations", http://www.commondreams.org/headlines01/0411-01.htm

Faux J, 2003, 'How NAFTA failed Mexico” The American Prospect 14(7), 35-37, http://www.protest.org/print/V14/7/faux-j.html

Figueras T, Olkon S, Merzer M, 2003, "Big police presence; few clashes" The Miami Herald 21 November, page $1 \mathrm{~A}$

Fisher W, Ponniah T (Eds), 2003 Another World is Possible: Popular Alternatives to Globalization at the World Social Forum (Zed Books and Fernwood, New York)

FTAA, 2003, "Free Trade Area of the Americas 8th Ministerial Meeting: Ministerial Declaration", Miami, FL, 20 November, http://www.ftaa-alca.org/Ministerials/Miami/Miami_e.asp

FTAA, 2004, "Special Summit of the Americas: Declaration of Nuevo León", Monterrey, Mexico, 13 January, http://www.summit-americas.org/SpecialSummit/Declarations/ Declaration\%20of\%20Neuvo\%20Leon\%20-\%20final.pdf

FTAA Miami Video Working Group, 2004 The Miami Model documentary film Indymedia Video, http://video.indymedia.org/en/

Glassman J, 2002, "From Seattle (and Ubon) to Bangkok: the scales of resistance to corporate globalization" Environment and Planning D: Society and Space $20513-533$

Heyman R, 2004, "Jumping scales and sinking ships: public space in Seattle", in Locating Civil Society: Knowledge, Pedagogy, and the Production of Public Space PhD dissertation, Department of Geography, University of Washington, Seattle, WA, pp 13-61

Hogue I, Reinsborough P, 2003, "Lessons from Miami: information warfare in the age of empire", http://www.smartmeme.com

Jessop B, 1990 State Theory: Putting the Capitalist State in its Place (Polity Press, Cambridge)

Kennis A, 2003, "Media analysis of national and local media coverage of the FTAA", http://www.ftaaimc.org/or/2003/11/1394.shtml

Kirchner N, Lula da Silva L I, 2004, "Declaración de Copacabana", 16 March, http://www.deudaexterna.com/declaraciones/ArgentinaBrasilDecCopacabana.htm

Klein N, 2003, "The war on dissent" Globe and Mail 25 November, page 1

Lapham L, 2004, "Notebook: crowd control" Harper's Magazine October, pp 9-11

Media Mouse, 2003, "Report from morning direct actions against the FTAA in Miami", http://www.ftaaimc.org/en/2003/11/1545.shtml

Mertes T (Ed.), 2004 A Movement of Movements (Verso, New York)

Mitchell D, 1995, "The end of public space? People's Park, definitions of the public, and democracy" Annals of the Association of American Geographers 85108 - 133

Mitchell D, 2003 The Right to the City: Social Justice and the Fight for Public Space (Guilford Press, New York)

Neale J, 2002 You are G8, We are 6 billion: The Truth Behind the Genoa Protests (Vision Paperbacks, London)

Notes from nowhere (Ed.), 2003 We Are Everywhere: The Irresistible Rise of Global Anti-Capitalism (Verso, New York)

Poulantzas N, 2001 State Power Socialism (Verso, New York); first published in 1978

Preusse H, 2004 The New American Regionalism (Edward Elgar, Northampton, MA) 
Prokosch M, LoPresti T, 2004, "Next steps in the US global justice movement" Z Net 8 January, http://www.zmag.org/content/showarticle.cfm?ltemlD=4799

Public Citizen, 2003, "The ten year track record of the North American Free Trade Agreement: the Mexican economy, agriculture and environment", http://www.citizen.org/documents/ NAFTA_10_mexico.pdf

Pue W (Ed.), 2000 Pepper in Our Eyes: The APEC Affair (University of British Columbia Press, Vancouver)

Reuters, 2004, “Americas trade plan 'dead' says Venezuela's Chavez”, 2 April

Root Cause, 2003, "Community impact report", 11 November, http://www.therootcause.org/ images/CIR_eng\%202.pdf

Shaft J, 2003, "Despite massive police presence Root Cause has great rally", 19 November, http://www.ftaaimc.org/en/2003/11/838.shtml

Shepard B, Hayduk R (Eds), 2002 From ACT UP to the WTO: Urban Protest and Community Building in the Era of Globalization (Verso, New York)

Solnit R, 2003, 'Fragments of the future: the FTAA in Miami” Z Net 25 November, http://www.zmag.org/content/showarticle.cfm?SectionID $=13 \&$ ItemID $=4559$

Starhawk, 2003, "Miami: a dangerous victory", http://ftaaimc.org/en/2003/12/3006.shtml

The Economist 2003, "Brass, bolts and Brazil", 22 November, page 32

Uitermark J, 2004, "Looking forward by looking back: May Day protests in London and the strategic significance of the urban" Antipode $36706-727$

van Rompay J, 2004, "Brazil's strategy towards the FTAA", in Free Trade for the Americas?: The United States' Push for the FTAA Agreement Eds P Vizentini, M Wiesebron (Zed Books, London) pp $120-148$

Vizentini P, 2004, "The FTAA and US strategy: a southern point of view", in Free Trade for the Americas?: The United States' Push for the FTAA Agreement Eds P Vizentini, M Wiesebron (Zed Books, London) pp $11-22$

Vizentini P, Wiesebron M (Eds), 2004 Free Trade for the Americas?: The United States' Push for the FTAA Agreement (Zed Books, London)

Wainwright J, Prudham S, Glassman J, 2000, "The battles in Seattle: microgeographies of resistance and the challenge of building alternative futures" Environment and Planning D: Society and Space $185-13$

Wallach L, 2003, "The beginning of the end of FTAA: crisis leads to scale back in scope, punting hard decisions with no instructions to overcome differences", International Forum on Globalization website, http://www.ifg.org/news/ftaa/ftaalori.htm

Wallach L, 2004, "Three strikes, is FTAA NAFTA-expansion out? Latest meeting to revive Free Trade Area of the Americas collapses in Buenos Aires", http://www.citizen.org/pressroom/ release.cfm? ID $=1679$

Weisbrot M, Rosnick D, Baker D, 2004, "NAFTA at ten: the recount", http://www.cepr.net/ publications/NAFTA_at_Ten.pdf

Wiesebron M, 2004, 'The forgotten society: lack of transparency and democracy", in Free Trade for the Americas?: the United States' Push for the FTAA Agreement Eds P Vizentini, M Wiesebron (Zed Books, New York) pp $77-93$

WTO, 2003 Preparations for the Fifth Session of the Ministerial Conference: Draft Cancún Ministerial Text 24 August, World Trade Organization, Geneva, JOB(03)/150/Rev.1

WTO, 2004a, "WT/L/579: Doha work programme: decision adopted by the General Council on 1 August 2004", 2 August, World Trade Organization, Geneva

WTO, 2004, "Doha development agenda July 2004 package: meeting summary 31 July”, World Trade Organization, Geneva, http://www.wto.org/english/news_e/news04_e/ dda_package_sum_31july04_e.htm

Yu P, 2003, "Globaphobia: why the arguments against the FTAA were flawed", http://www.cnn.com/ 2003/LAW/11/25/findlaw.analysis.yu.ftaa/, http://writ.findlaw.com/commentary/20031125_yu.html 
Conditions of use. This article may be downloaded from the E\&P website for personal research by members of subscribing organisations. This PDF may not be placed on any website (or other online distribution system) without permission of the publisher. 